\title{
Mercury in blue shark (Prionace glauca) and shortfin mako (Isurus oxyrinchus) from north-eastern Atlantic: Implication for fishery management
}

\author{
Biton-Porsmoguer Sebastian ${ }^{1}$, Banaru Daniela ${ }^{1,}{ }^{*}$, Boudouresque Charles F. ${ }^{1}$, Dekeyser Ivan ${ }^{1}$, \\ Bouchoucha Marc ${ }^{2}$, Marco-Miralles Francoise ${ }^{2}$, Lebreton Benoit ${ }^{3}$, Guillou Gael ${ }^{3}$, \\ Harmelin-Vivien Mireille ${ }^{1}$
}

\footnotetext{
${ }^{1}$ Toulon Univ, Aix Marseille Univ, CNRS INSU, IRD,MIO,UM 110, Campus Luminy, F-13288 Marseille, France.

2 IFREMER, CS 20203, F-83507 La Seyne Sur Mer, France.

${ }^{3}$ Univ La Rochelle, CNRS, UMR 7266, Littoral Environm \& Soc, 2 Rue Olympe Gouges, F-17000 La

Rochelle, France.
}

* Corresponding author : Daniela Banaru, email address : daniela.banaru@univ-amu.fr

\begin{abstract}
:
Pelagic sharks (blue shark Prionace glauca and shortfin mako Isurus oxyrinchus) caught by long-line Spanish and Portuguese fleets in the NE Atlantic, were sampled at Vigo fish market (Spain) for total mercury $(\mathrm{Hg})$ analysis. $\mathrm{Hg}$ concentration in white muscle increased with size and weight in both species, but at a higher rate in shortfin mako than in the blue shark. No difference was found with sex, year and season. Spatial variation was observed in the blue shark with higher $\mathrm{Hg}$ values in the North of the Azorean archipelago, but not in the shortfin mako. These high-level predators are particularly susceptible to bioaccumulate contaminants $(\mathrm{Hg})$ in their tissues (muscle). However, a significant positive relationship between $\mathrm{Hg}$ concentration and trophic level $(\delta 15 \mathrm{~N})$ of individuals was observed only in the shortfin mako. Most sharks landed were juveniles which presented $\mathrm{Hg}$ concentration lower than the maximum limit allowed by the European Union (1 mg kg-1 wet weight) for marketing. However, concentrations above this threshold were most recorded in blue sharks larger than $250 \mathrm{~cm}$ total length (TL) and in shortfin makos larger than $190 \mathrm{~cm}$ TL, raising the question of the commercialization of large-sized individuals.
\end{abstract}




\section{Highlights}

- Total mercury $(\mathrm{Hg})$ concentrations were analyzed in the muscle of Prionace glauca and Isurus oxyrinchus. - These high-level predators, particularly susceptible to bioaccumulate $\mathrm{Hg}$, were caught by long-liners in the NE Atlantic. P $P$. glauca larger than $250 \mathrm{~cm}$ total length recorded $\mathrm{Hg}$ concentrations above maximum limit allowed by the European Union. I. oxyrinchus larger than $190 \mathrm{~cm}$ total length recorded $\mathrm{Hg}$ concentrations above maximum limit allowed by the European Union. The question of the commercialization of large-sized individuals for these two species was raised.

Keywords : Mercury, Pelagic sharks, Blue shark, Shortfin mako, Long-line fishery, NE Atlantic 


\section{Introduction}

Long-line Spanish and Portuguese fleets which exploit offshore north-eastern Atlantic waters target pelagic sharks, particularly the blue shark Prionace glauca (Linnaeus, 1758) and the shortfin mako Isurus oxyrinchus, Rafinesque, 1810, along with the swordfish Xiphias gladius Linnaeus, 1758. For the past 15 years (2001-2015), the mean landings per year of blue shark represent 2,167 tonnes (63\% of long-line landings) and 501 tonnes (14\%) for the shortfin mako at the fish market of Vigo in Galicia, Spain (Xunta da Galicia, 2008, comm. Pers; ICCAT, 2015). Sharks are essentially sold for human consumption (meat and fin).

The blue shark can reach $380 \mathrm{~cm}$ in total length (TL) and could live up to 16 years (20 years $\max$ ) in the North Atlantic (Skomal and Natanson, 2003). No difference of size at age with sex is observed, except for the largest individuals (Nakano and Steven, 2008). Blue shark females are sexually mature at $200 \mathrm{~cm}$ TL (5-6 years) and males at $180 \mathrm{~cm}$ TL (4-5 years) (Moreno, 2004; Compagno et al., 2005). The shortfin mako presents a heavier body than the blue shark, a longer maximum size $(440 \mathrm{~cm}$ ) and a longer life span (30 years max) (Natanson et al., 2006). Median size and age at maturity would be about $195 \mathrm{~cm}$ TL and 5-6 years for males, and $280 \mathrm{~cm}$ TL and 7-10 years for females, which present a larger size than males (Barreto et al., 2016). However, information on age and growth of both shark species is conflicting and still a matter of debate (Skomal and Natanson, 2003; Barreto et al., 2016). Spanish and Portuguese long-liners target mostly small individuals, as juveniles represent the major part of shark landings at Vigo fish market for both species (73\% of blue sharks and 94\% of shortfin mako) (Biton Porsmoguer, 2015).

Their position as high-level predators in the marine food web (Ferretti et al., 2010), makes them especially susceptible to contain high concentration of contaminants and particularly mercury ( $\mathrm{Hg}$ ) (Storelli et al., 2002), as $\mathrm{Hg}$ is known to bioamplify along food webs, increasing with the trophic level of organisms (Harmelin-Vivien et al., 2009, 2012; Lavoie et al., 2013). Trophic level of organisms is routinely determined by the nitrogen isotopic ratio $\left({ }^{15} \mathrm{~N} /{ }^{14} \mathrm{~N}\right)$, expressed relative to a standard as $\delta^{15} \mathrm{~N}$, which tends to increase with the size of individuals and from prey to predator, as most contaminants do (Cabana and Rasmussen, 1994; Booth and Zeller, 2005; Cossa et al., 2012). Mercury is a highly toxic contaminant present in all compartments of the biosphere entering marine food webs from natural and anthropogenic sources (Cossa et al., 
2009), susceptible to impact aquatic ecosystems (McKinley and Johnston, 2010). Adverse health effects of $\mathrm{Hg}$ on humans include toxic effects on the nervous, digestive, cardiovascular and immune systems, and alterations of foetal neurodevelopment (Castoldi et al., 2003; Diez, 2008). As consumption of marine organisms contributes to most $\mathrm{Hg}$ intake in humans, the maximum level of this contaminant in marine products have been laid down by European Commission regulations and set at $1 \mathrm{mg} \mathrm{kg}^{-1}$ wet weight (ww) for high-level pelagic predators (European Commission, 2006: Regulation No 1881/2006). Fisheries Department from Galician region is supposed to apply the European regulation and must control sanitary state for all landed sea products (Law 11/2008, December $3^{\text {rd }}$ 2008; Xunta da Galicia, 2008). But are the sharks landed and commercialized in Galicia fulfil all these requirements?

The main goals of the present study were thus to: (i) measure the mercury concentration in the muscle of sharks caught in the north-eastern Atlantic Ocean and sold at Vigo fish market, (ii) determine the influence of size, weight, sex, trophic level, zones, season and year on $\mathrm{Hg}$ content in these sharks, and (iii) consider the possible implications for the fishery management.

\section{Material and methods}

\subsection{Sampling and stomach content analysis}

Sharks were caught by Spanish and Portuguese longline vessels in the north-eastern Atlantic in five zones (A to F) between the Iberian Peninsula and the Azores archipelago $\left(15^{\circ}-35^{\circ} \mathrm{W}\right.$ and $30^{\circ}-45^{\circ} \mathrm{N}$ ), in 2012 and 2013 (Fig. 1). A total of 40 blue shark (Prionace glauca) and 48 shortfin mako (Isurus oxyrinchus) landed at the fish market of Vigo (Spain) were sampled (Table 1). The smallest and largest blue shark and shortfin mako measured 74 and $284 \mathrm{~cm}$, and 100 and $219 \mathrm{~cm}$ total length (TL), respectively. White muscle samples, one centimeter beneath the skin, were extracted from each individual, put in plastic bags and stored frozen at $-20^{\circ} \mathrm{C}$. Once at the laboratory, samples were cleaned with distilled water before freeze-drying, grinding and analyzing for total mercury $(\mathrm{Hg})$ and nitrogen stable isotopes $\left(\delta^{15} \mathrm{~N}\right)$. Shark stomachs were extracted and stored at $-20^{\circ} \mathrm{C}$. After identification and weighing (wet weight ww) of the prey found in stomach contents, those recently consumed (in good state of conservation) were freeze- 
dried and analyzed in the same way as shark muscle samples. Total wet weights of partially digested prey were reconstructed according to the size of their hard pieces (beaks for cephalopods and otoliths or vertebrae for teleost fish) using pre-established relationships (Biton Porsmoguer, 2015). Reconstructed weight percentages (\%ww) of the main prey types found in stomach contents were then determined for both shark species.

\subsection{Mercury and stable isotope analyses}

Total $\mathrm{Hg}$ concentrations were determined with the semi-automated atomic absorption spectrophotometer AMA 254 (Altec Ltd, Prague, Czech Republic) with a detection limit of 0.003, following the procedure described in Cossa et al. (2009). Hg quantification procedure consisted in three automatic sequences: (1) ashing at $550^{\circ} \mathrm{C}$ of the freeze dried sample for $\mathrm{Hg}$ volatilisation, (2) evolved elemental $\mathrm{Hg}$ amalgamation on a gold trap, (3) atomic absorption spectrophotometric measurement of the $\mathrm{Hg}$ collected after heating the gold trap at $800^{\circ} \mathrm{C}$. The accuracy of measurement was assessed every ten samples using certified reference materials from the National Research Council of Canada (fish muscle tissues DORM-1 and DORM-2). $\mathrm{Hg}$ concentration level of samples was initially expressed as $\mathrm{Hg}$ dry weight (dw) concentration in fish muscle or prey muscle samples. However, as $\mathrm{Hg}$ concentrations are expressed in wet weight (ww) in international and European regulations, dry weight concentrations were converted into wet weight concentrations, considering that $\mathrm{dw}=5 \mathrm{ww}$ (Magalhães et al., 2007).

Stable isotope analyses were performed with a continuous flow mass spectrometer (Delta V Advantage, Thermo Scientific, Bremen, Germany) coupled to an elemental analyzer (Flash EA 1112 Thermo Scientific, Milan, Italy). N stable isotope ratios were expressed in the standard $\delta$ notation: $\delta{ }^{15} \mathrm{~N} \%=\left[\left(\mathrm{R}_{\text {sample }} / \mathrm{R}_{\text {standard }}\right)-1\right] \times 10^{3}$, where $\mathrm{R}$ is the ratio ${ }^{15} \mathrm{~N} /{ }^{14} \mathrm{~N}$ in sample and standard (atmospheric air for nitrogen). Accuracy of measurement was estimated by replicate measurements of internal standard (acetanilide) and was lower than $0.1 \%$.

\subsection{Data analysis}

Quantification of Hg concentrations in sharks' diet: The diets of the blue shark and shortfin mako in the sampling area have been previously studied (Biton Porsmoguer et al., 2013, 2015). 
The blue shark mainly fed on cephalopods, then teleost fish and rarely cetaceans, while the shortfin mako mainly preyed on teleost fish, then cephalopods, and occasionally cetaceans and chelonians. The importance in weight (\% dry weight) of each prey type was determined for each species and $\mathrm{Hg}$ concentration of their diet was quantified with the equation as in HarmelinVivien et al. (2012):

$$
\mathrm{C}_{\operatorname{diet}(\mathrm{i})}=\sum\left[\mathrm{C}_{\text {prey(x) }} \times \mathrm{W}_{\operatorname{prey}(\mathrm{x})(\mathrm{i})}\right]
$$

where $\mathrm{C}_{\text {diet(i) }}$ is the $\mathrm{Hg}$ concentration in the diet of the shark species (i), $\mathrm{C}_{\text {prey(x) }}$ is the $\mathrm{Hg}$ concentration of the prey $(x), W_{\text {prey(x)(i) }}$ is the percentage in weight of the prey (x) in the (i)th shark species, and $\sum$ the sum of the product for all the $(\mathrm{x})$ prey types. In a similar way, the $\delta^{15} \mathrm{~N}$ value of the diet of each shark species was determined following the equation:

$$
\delta^{15} \mathrm{~N}_{\text {diet(i) }}=\sum\left[\delta^{15} \mathrm{~N}_{\text {prey(x) }} \mathrm{x} \mathrm{W}_{\text {prey(x)(i) }}\right]
$$

where $\delta^{15} \mathrm{~N}_{\text {diet(i) }}$ is the $\delta^{15} \mathrm{~N}$ of the diet of the shark species (i), $\delta^{15} \mathrm{~N}_{\text {prey(x) }}$ is the $\delta^{15} \mathrm{~N}$ of the prey $(\mathrm{x}), \mathrm{W}_{\text {prey(x)(i) }}$ is the percentage in weight of the prey $(\mathrm{x})$ in the (i)th shark species, and $\sum$ the sum of the product for all the $(\mathrm{x})$ prey types.

Biomagnification factor calculations: A mean biomagnification factor (BMF) was determined for the two sharks in the north-eastern Atlantic following Fisk et al. (2001), based on mean $\mathrm{Hg}$ concentration and trophic level of sharks and their diet, using the following equation:

$\mathrm{BMF}_{\text {shark(i) }}=\left[\left(\mathrm{C}_{\text {shark (i) }} / \mathrm{C}_{\operatorname{diet}(\mathrm{i})}\right) /\left(\delta^{15} \mathrm{~N}_{\text {shark(i) }} / \delta^{15} \mathrm{~N}_{\operatorname{diet}(\mathrm{i})}\right)\right]$

Where $\mathrm{C}_{\text {shark(i) }}$ is the $\mathrm{Hg}$ concentration in the shark species (i), $\mathrm{C}_{\text {diet(i) }}$ is the $\mathrm{Hg}$ concentration in the diet of the (i) shark species, $\delta^{15} \mathrm{~N}_{\text {shark(i) }}$ is the trophic level of the (i) shark species, and $\delta^{15} \mathrm{~N}_{\text {diet(i) }}$ is the trophic level of the diet of the (i) shark species. This factor is based on the assumption that mercury concentration in a predator depends on those of its prey, corrected for trophic level difference between predator and prey. We replace the trophic level estimation used by Fisk et al. (2001) by $\delta^{15} \mathrm{~N}$ values, which represents a more accurate estimation of organism trophic position.

Statistical analysis: As the number, size, weight and sex of individuals differed between sampling zones and species, differences were tested by ANCOVA to remove the effects of these parameters and consider only the factor tested. Relationships between $\mathrm{Hg}$ content and sharks 
size, weight and $\delta^{15} \mathrm{~N}$ were tested by Pearson's linear correlation on $\log _{10}$ transformed $\mathrm{Hg}$ concentrations to linearize the regression and stabilize the variances. Differences in slope and elevation were tested by appropriate $t$-test.

\section{Results}

\subsection{Influence of biological parameters on $\mathrm{Hg}$ level}

In both species, mercury concentration did not vary with sex for individuals of similar size or weight (ANCOVA, all p >0.05), suggesting similar feeding habits in males and females. Thus, sexes were combined for further analyses. Total $\mathrm{Hg}$ level in muscle ranged from 0.14 to $1.71 \mathrm{mg}$ $\mathrm{kg}^{-1} \mathrm{ww}$ in the blue shark and from 0.12 to $2.57 \mathrm{mg} \mathrm{kg}^{-1} \mathrm{ww}$ in the shortfin mako (Table 2). $\mathrm{Hg}$ concentration increased significantly with size and weight, as significant linear relationships were observed between $\mathrm{Log} \mathrm{Hg}$ and total length (TL cm) in the two species (Fig. 2), and between $\log \mathrm{Hg}$ and total weight of individuals (W kg ww) ( $\log \mathrm{Hg}=0.009 \mathrm{~W}-0.555, \mathrm{R}^{2}=0.59, \mathrm{p}<$ 0.001 in blue shark; $\log \mathrm{Hg}=0.012 \mathrm{~W}-0.630, \mathrm{R}^{2}=0.66, \mathrm{p}<0.001$ in mako). Whatever the parameter considered (size or weight), the slope of the regression was higher in the shortfin mako than in the blue shark, suggesting different bioaccumulation processes between the two species. However, the relationship between $\mathrm{Hg}$ concentration and the trophic level of individual, expressed as $\delta^{15} \mathrm{~N}$ values, was significant only for mako $\left(\log \mathrm{Hg}=0.169 \delta^{15} \mathrm{~N}-2.181, \mathrm{R}^{2}=\right.$ $0.10, \mathrm{p}<0.05)$, but not in the blue shark $\left(\log H g=-0.069 \delta^{15} \mathrm{~N}+0.422, \mathrm{R}^{2}=0.02, \mathrm{p}=0.197\right)$.

\subsection{Geographical and temporal variations}

In blue shark, significantly higher mean $\mathrm{Hg}$ concentrations were recorded in individuals collected in zone $\mathrm{A}$, than in zone $\mathrm{B}, \mathrm{D}$ and $\mathrm{F}$ in which blue shark had similar lower concentrations for individuals of similar size (ANCOVA $F=3.46, p=0.026$ ) or weight (ANCOVA F $=3.37, \mathrm{p}=0.029$ ). Blue sharks presented 1.6 higher $\mathrm{Hg}$ concentrations in zone $\mathrm{A}$ than in the three other zones. Pearson's linear correlations between $\mathrm{Log} \mathrm{Hg}$ and size presented similar slopes in all zones, but a higher intercept value in zone A (Fig. 3), suggesting the influence of environmental differences between zone A in the North of the Azores archipelago 
and the other zones, rather than a biological difference between individuals. In contrast, no difference of $\mathrm{Hg}$ level among zones was observed for the shortfin mako, taken into account differences in size or weight of individuals in the different zones (ANCOVA, F = 2.46, p = 0.086 for size; $\mathrm{F}=1.49, \mathrm{p}=0.242$ for weight). In both species, $\mathrm{Hg}$ concentration in muscle did not significantly vary with year (2012 vs 2013) nor season (spring vs autumn) (ANCOVA, all p > $0.05)$.

\subsection{Biomagnification factor and influence of diet}

The biomagnification factor BMF takes only into account the last trophic level of the food web analyzed (the predator and its prey). $\mathrm{Hg}$ level and $\delta^{15} \mathrm{~N}$ of the main prey ingested by these two sharks displayed highly variable values (Table 3). The lowest $\mathrm{Hg}$ concentrations were recorded in pelagic teleost prey fish, such as Scomber sp. $\left(0.02 \mathrm{mg} \mathrm{kg}^{-1} \mathrm{ww}\right)$ and Scomberesox saurus (0.08 $\left.\mathrm{mg} \mathrm{kg}^{-1} \mathrm{ww}\right)$, and the highest ones in some cephalopods (Illex sp., $2.24 \mathrm{mg} \mathrm{kg}^{-1} \mathrm{ww}$ ) and the cetacean Delphinus delphis $\left(1.77 \mathrm{mg} \mathrm{kg}^{-1} \mathrm{ww}\right)$. The lowest $\delta^{15} \mathrm{~N}$ value was observed in the teleost fish Euthynnus alleteratus (9.7\%) and the highest one in the cephalopod Ancistroteuthis lichtensteini (12.9\%o). No significant correlation was found between $\log \mathrm{Hg}$ and $\delta^{15} \mathrm{~N}$ in prey, or $\delta^{15} \mathrm{~N}$ in prey and sharks combined $\left(\mathrm{R}^{2}=0.06, \mathrm{p}>0.05\right.$ for both regressions). The blue shark and mako ingested then prey with various $\mathrm{Hg}$ burden, some presenting higher $\mathrm{Hg}$ concentration and trophic level than them. The blue shark mainly fed on cephalopods (76\% by weight), teleost fish $(18 \%)$ and cetaceans $(0.03 \%)$, while the shortfin mako preyed mainly on teleost fish (66\% by weight), cephalopods $(27 \%)$, cetaceans $(0.05 \%)$ and sea turtles $(0.03 \%)$. When growing the blue shark consumed less cephalopods and more teleosts and cetaceans, while the shortfin mako ingest less teleosts and more cetaceans and chelonians. Mean $\mathrm{Hg}$ concentration and $\delta^{15} \mathrm{~N}$ in diet was higher for the blue shark than for mako, globally and in most size classes (Table 4), while the reverse was observed in shark muscle with generally higher $\mathrm{Hg}$ level in mako muscle than in blue shark muscle. Mean BMF value was low $(<1)$ in the blue shark, but higher than 1 in the shortfin mako (Table 4), suggesting Hg bioamplification from diet to predator in the shortfin mako only. When the different size classes were considered, it was observed that BMF tended to increase with the size of individuals in both species, but not in a linear way. BMF remained always $<1$ in the blue shark suggesting no $\mathrm{Hg}$ bioamplification in this species. In the shortfin 
mako, no bioamplification was recorded in the smaller individuals ( $<130 \mathrm{~cm}$ TL) with BMF $<1$, while $\mathrm{Hg}$ bioamplification occurred for larger-sized individuals (particularly >200 cm TL) with BMF largely $>1$. Such results indicated no straightforward relationship between $\mathrm{Hg}$ level of prey and predator, but rather suggested differences in metabolism and/or prey consumption rate between the two shark species.

\subsection{Mercury in sharks and food safety}

The significant exponential relationship evidenced between $\mathrm{Hg}$ level in muscle and body size of sharks revealed that some individuals presented higher mean $\mathrm{Hg}$ concentration than the European regulatory threshold $\left(1.0 \mathrm{mg} \mathrm{kg}^{-1} \mathrm{Ww}\right)$ for the commercialization of high-level pelagic predators. Hg level above this value was observed for individuals over $210 \mathrm{~cm}$ TL in the blue shark and 154 $\mathrm{cm}$ TL in mako (Fig 4 and 5). We defined (i) a size range of potential risk for consumers with individuals between 210-242 cm TL for the blue shark (Fig 4), and 154-182 cm TL for mako

(Fig 5), as such highly contaminated fish were present but not numerous in this size range, and (ii) a size at risk (242 cm TL for the blue shark and $182 \mathrm{~cm}$ TL in mako) above which most individuals (or all) presented higher $\mathrm{Hg}$ level than the allowed EU limit. These last lengths corresponded thus to a size-at-risk for human consumption and then the commercialization of these shark individuals.

\section{Discussion}

\subsection{Bioaccumulation of $\mathrm{Hg}$ in blue shark and shortfin mako}

In both shark species $\mathrm{Hg}$ concentration in muscle was positively correlated with length and consequently age (Fig. 2). Increase of $\mathrm{Hg}$ level in organism as they were growing and getting older is a well-known bioaccumulation process in marine organisms, particularly in teleost fish (Cossa et al. , 2012; Cresson et al., 2014) and high-level predators like sharks (Storelli et al., 2001, 2002; Branco et al., 2004, 2007) and cetaceans (André et al., 1991). This age-related increase in $\mathrm{Hg}$ content is related to an efficient accumulation of methylmercury bound to protein 
sulfhydryl groups which is slowly eliminated (Amlund et al., 2007). But many parameters are susceptible to influence the bioaccumulation of $\mathrm{Hg}$ in organism along with age, such as growth rate, reproduction, metabolic activity, $\mathrm{Hg}$ concentration in prey and feeding rate (Trudel and Rasmussen, 2006; Cossa et al., 2012). Diet is recognized as the main pathway of Hg intake in high-level predators (Boening, 2000). Both shark species ingested prey of various $\mathrm{Hg}$ content and $\delta^{15} \mathrm{~N}$ values, some being more contaminated and positioned at a higher trophic level than sharks (Table 3 ). Hg content and $\delta^{15} \mathrm{~N}$ in diet did not increase with shark size (Table 4). Thus the hypothesis of an increase in $\mathrm{Hg}$ uptake when sharks were growing linked to an increase in prey $\mathrm{Hg}$ content was not supported by our study. Larger sharks did not seem to feed at a higher more contaminated trophic level than smaller ones, as observed by McMeans et al. (2010) in Arctic sharks. Feeding on larger prey did not imply to feed on more contaminated or higher trophic level organisms. No relationship between $\mathrm{Hg}$ concentration and $\delta^{15} \mathrm{~N}$ was found in the blue shark, as also observed by Rumbold et al. (2014) for coastal sharks in Florida or EscobarSanchez et al. (2010) for Prionace glauca at Baja California. Positive relationships between $\mathrm{Hg}$ and $\delta^{15} \mathrm{~N}$ as observed in mako, were recorded only for a few, but not most, shark species analyzed in Australia (Pethybridge et al., 2011) or in the Celtic sea (Domi et al. 2005). If Hg is efficiently accumulated in shark tissues with a very slow elimination rate (Amlund et al., 2016), the fractionation of $\delta^{15} \mathrm{~N}$ between diet and shark tissue seems to be also slower in sharks than in teleost fish (Hussey et al. 2012), suggesting particular metabolic activity related to nitrogen cycling in elasmobranchs. The absence of influence of sex, season and year on mercury level in both species can be explained by the high mobility of these sharks regardless of sex (Queiroz et al., 2016) and the large spectrum of prey consumed at different seasons during the two years (Biton Porsmoguer et al., 2013, 2015).

A higher increase in $\mathrm{Hg}$ content with size was observed in the shortfin mako compared with blue shark (Fig. 2), suggesting different bioaccumulation processes between the two species (age, diet, activity and/or metabolism). While the blue shark and the shortfin mako are long-lived species (with a higher life span for mako) (Skomal and Natanson, 2003; Natanson et al., 2006), the age of specimens analyzed in this study ranged likely from 1 to 10 years for both species with a majority of juveniles, especially in the shortfin mako (Biton Porsmoguer, 2015). Shortfin mako were heavier than blue sharks at the same size, invalidating the possibility of a dilution of $\mathrm{Hg}$ by growth in the blue shark to explain its lower $\mathrm{Hg}$ content. Higher $\mathrm{Hg}$ content of diet in mako was 
also not supported by our results (Table 4). Thus, the higher $\mathrm{Hg}$ concentration observed in the shortfin mako could not be attributed to an older age, a slower growth rate or a higher $\mathrm{Hg}$ content of its prey. Differences in feeding rate and metabolic activity may explain the higher Hg uptake with size observed in mako compared to blue shark. Isurus oxyrinchus belongs to the warmbodied Lamnidae which present an elevated aerobic metabolism compared to their ectothermic relatives like the blue shark (Carcharhinidae) (Shadwick and Goldbogen, 2012). The shortfin mako can maintain higher temperatures than the surrounding water ones in musculature, brain, eyes and viscera ( 1 to $10^{\circ} \mathrm{C}$ higher than ambient temperature) (Carey, 1982). Therefore, it needs to eat more frequently than the blue shark and accumulates more mercury due to an increased feeding rate. This was reflected by a lower vacuity index in the shortfin mako (36\%) compared to blue shark (47\%) (Biton Porsmoguer, 2005).

\subsection{Regional differences}

Mercury levels recorded in the blue shark in this study $\left(0.14-1.71 \mathrm{mg} \mathrm{kg}^{-1} \mathrm{ww}\right)$ were in agreement with values previously reported in different studies performed in the north Atlantic Ocean (0.16-1.84 $\mathrm{mg} \mathrm{kg}^{-1} \mathrm{ww}$ ) except the south coast of Brazil (Carvalho et al., 2014), and other oceanic regions (0.27-1.24 $\left.\mathrm{mg} \mathrm{kg}^{-1} \mathrm{ww}\right)$ (Table 5). This may be related to the high mobility of these sharks able to cover large areas for feeding and to their dietary opportunism. However, Branco et al. (2007) record a higher accumulation rate of total mercury with size in Prionace glauca from the equatorial Atlantic (0.68-2.50 $\left.\mathrm{mg} \mathrm{kg}^{-1} \mathrm{ww}\right)$ compared with specimens from the Azores archipelago (0.22-1.30 $\left.\mathrm{mg} \mathrm{kg}^{-1} \mathrm{ww}\right)$. They rely this pattern to higher $\mathrm{Hg}$ concentration in prey, as well as differences in quantity and type of food eaten in the Equator. Such a hypothesis was not relevant in our study, as the rate (regression slope) of $\mathrm{Hg}$ increase in blue shark with size was similar in all zones (Fig. 3). Higher Hg concentrations in the Azores could not be attributed to gender, as no difference with sex was observed. The higher intercept value of the linear regression for specimens from the Azores suggested rather the influence of environmental conditions with probably higher $\mathrm{Hg}$ concentrations in sea water and prey in this zone, but no difference in metabolism, feeding rate or prey types between populations. The Azores archipelago is a volcanic region with naturally high mercury level in sea water and sediment (Guest et al., 1999) that may explain the significantly higher levels of $\mathrm{Hg}$ found in the blue 
sharks of zone A. Moreover, the Azores archipelago constitutes probably a nursery area for the blue shark and juveniles can stay in this area at least for two years (Vandeperre et al., 2014), accumulating thus a higher $\mathrm{Hg}$ burden during this time. However, in the absence of $\mathrm{Hg}$ concentration analysis in seawater and a sufficient number of prey in the different zones, we cannot test this hypothesis.

No difference in $\mathrm{Hg}$ concentration among zones was observed for the shortfin mako in this study. This homogeneity was probably due to the high swimming activity of this species, which moves frequently between distant zones (Kohler et al., 2002). The $\mathrm{Hg}$ values recorded in the shortfin mako were high (0.12-2.57 $\left.\mathrm{mg} \mathrm{kg}^{-1} \mathrm{ww}\right)$ and in the range of those observed for this species in the north Atlantic and other oceans (0.15-3.12 $\left.\mathrm{mg} \mathrm{kg}^{-1} \mathrm{ww}\right)$ (Table 5).

\subsection{Biomagnification of $\mathrm{Hg}$ in sharks}

Mercury, under its organic monomethylmercury form, is one of the few trace metals to biomagnify along food webs (Gray, 2002). Biomagnification is assumed when BMF factor (concentration in predator/concentration in diet corrected from their respective trophic level) is $>1$ (Fisk et al., 2001). Biomagnification of $\mathrm{Hg}$, i.e. the increase of $\mathrm{Hg}$ concentration from diet to predator, was observed only in the shortfin mako, not in the blue shark (Table 4). These two sharks consumed prey with a great variability in both $\mathrm{Hg}$ concentration and $\delta^{15} \mathrm{~N}$ value (Table 3 ). For the blue shark, this resulted in a higher $\mathrm{Hg}$ content in diet than shark muscle for all size classes, leading up to a BMF always <1, while slightly increasing with size. For the shortfin mako, higher $\mathrm{Hg}$ content in shark muscle compared with diet and BMF values $>1$ were observed from individuals larger than $130 \mathrm{~cm}$, and more significantly in mako $>200 \mathrm{~cm}$. However, BMF calculation should be considered cautiously. Only a small number of prey could be analyzed in this study, the same mean $\mathrm{Hg}$ and $\delta^{15} \mathrm{~N}$ values for prey groups were used for all size-classes of both sharks, while they could prey on different species (Biton Porsmoguer, 2015), and the time lag between ingestion and assimilation of prey was not considered. Stomach content offered a snap shot of shark's diet when caught, while muscle Hg concentration reflected food assimilation over several months. Nonetheless, similar results are reported by Maz-Courrau et al. (2012) at Baja California with $\mathrm{Hg}$ biomagnification in the shortfin mako but not in the blue shark. The absence of any $\mathrm{Hg}$ biomagnification in P. glauca is also observed by Escobar-Sánchez et al. 
(2010). Difference in BMF factor between the two species, with $\mathrm{Hg}$ biomagnification occurring only in the shortfin mako is probably related with their metabolic differences (endothermy in mako vs ectothermy in blue shark) (Shadwick and Goldbogen, 2012) as discussed above, with a positive relationship between $\mathrm{Hg}$ content and $\delta^{15} \mathrm{~N}$ in the shortfin mako and not in blue shark.

\subsection{Food safety and fishery implication}

The mean values of mercury level in the muscle of blue shark and shortfin mako analysed in this study were lower than the upper limit allowed by the European Union in high-level pelagic predators for human consumption ( $1 \mathrm{mg} \mathrm{kg}^{-1} \mathrm{ww}$ ) (Table 2). However, $\mathrm{Hg}$ concentration exceeded the legal EU standard in larger individuals, due to an exponential increase in $\mathrm{Hg}$ content with size in both species (Fig. 4 and 5). Above $242 \mathrm{~cm} \mathrm{TL}$ in $P$. glauca and $182 \mathrm{~cm} \mathrm{TL}$ in I. oxyrinchus most, if not all, individuals exhibited $\mathrm{Hg}$ content well above the EU allowed limit, representing a size at risk for the consumption of these species. Mercury concentration well above European and international regulatory thresholds in sharks is widely reported in the literature, whatever the ecology, geographic distribution or feeding habits of species (Storelli et al., 2002; Branco et al., 2004, 2007; Pethybridge et al., 2010; Escobar-Sánchez et al., 2011; de Carvalho et al., 2014; Cresson et al., 2014; Mc Kinney et al., 2016, and references in Table 5). All authors raise the heath issue of shark, and more generally high-level predator, consumption. However, $\mathrm{Hg}$ concentration value alone does not seem to be sufficient to evaluate the toxicity of marine organisms for human consumption, but rather the ratio $\mathrm{Hg}: \mathrm{Se}$, as selenium is known to play a protective role against the toxic effects of $\mathrm{Hg}$ and enhance detoxifying mechanisms (Branco et al., 2007; Khan and Wang, 2009). But studies on sharks record high Hg:Se values (Kaneko and Ralston, 2007; Escobar-Sánchez et al., 2011) or a decrease in this ratio with age, which leaves unsold the problem of $\mathrm{Hg}$ toxicity in larger older sharks.

The commercialisation of blue shark ( $>242 \mathrm{~cm} \mathrm{TL}$ ) and mako (>182 cm TL) exceeding the size at risk is thus an issue for Galician Fishery Authorities in terms of compliance with European legislation. The shark fisheries are not regulated by any measure (quotas and size limits) in Spain. According to our results, in terms of human food safety, we recommend not to keep on board or land sharks over these sizes for individuals caught between the Azores Archipelago and the Iberian Peninsula. However, this measure may lead to an increase in finning practice 
(prohibited in the EU in 2003 with application for Spain and Portugal in June 2013). Therefore maritime control should be enforced for the strict application of the Council Regulation (EC No 1185/2003). Furthermore, some nursery areas, such as the Azores Archipelago (Vandeperre et al., 2014), Gulf of Cadix (Compagno et al., 2005), and north of Galicia (Biton Porsmoguer, pers. com.), may concentrate big blue shark females exceeding the size at risk for mercury level (size with $\left.\mathrm{Hg}>1 \mathrm{mg} \mathrm{kg}^{-1} \mathrm{ww}\right)$. Within these areas shark fishing should be prohibited or at least regulated.

\section{Conclusions}

Mercury concentrations in muscle of the blue shark P. glauca and the shortfin mako $I$. oxyrinchus in north-eastern Atlantic were in the range of values reported in other regions for these cosmopolite sharks. An increase in $\mathrm{Hg}$ content with length and weight was observed in both species, but at a higher rate in the shortfin mako. Bioaccumulation of $\mathrm{Hg}$ with individual trophic level $\left(\delta^{15} \mathrm{~N}\right)$ and biomagnification from prey to predator was only observed in the shortfin mako, and likely related to its endothermic metabolism and higher feeding activity. The absence of significant difference between sexes, seasons and years in both species could be explained by the high mobility of these sharks and their feeding adaptation to different environmental conditions. Most blue shark and shortfin mako landed and sold at the fish market of Vigo (Spain) exhibited $\mathrm{Hg}$ concentration in muscle lower than the maximum limit allowed by the European Union for human consumption ( $\left.1 \mathrm{mg} \mathrm{kg}^{-1} \mathrm{ww}\right)$, as they were juveniles. However, $\mathrm{Hg}$ content above this legal threshold were recorded in the majority of adult blue shark larger than $242 \mathrm{~cm}$ LT and shortfin mako larger than $182 \mathrm{~cm} \mathrm{LT}$. Then, we recommend to avoid the capture and commercialization of individuals exceeding these respective lengths for the two species. In addition, a size range of potential risk was defined (from 210 to $242 \mathrm{~cm}$ for the blue shark and from 154 to $182 \mathrm{~cm}$ for the shortfin mako), in which some individuals might present $\mathrm{Hg}$ concentration above the legal limit. The landing of blue shark and shortfin mako in Vigo during the next decade should assume the implementation of management measures for the sustainable fishing exploitation and the conservation of these species. 


\section{Acknowledgments}

We gratefully acknowledge the Port Authority of Vigo (Spain), which authorized sampling, and the Captains of the fishing boats for allowing us to measure and dissect landed sharks before selling them. Mercury analysis were realized by the IFREMER at La Seyne-sur-Mer (France). Stable isotope analyses were performed at the LIENSs laboratory, University of La Rochelle. Thanks are also due to Michael Paul, a native English speaker, for English correction.

\section{References}

Amlund H., Lundebye A. K., Berntssen M.H.G., 2007. Accumulation and elimination of methylmercury in Atlantic cod (Gadus morhua L.) following dietary exposure. Aquat. Toxicol. 83: 323-330.

André, J., Boudou, A., Ribeyre, F., Bernarhd, M. 1991. Comparative study of mercury accumulation in Dolphins (Stenella coeruleoalba) from French Atlantic and Mediterranean coasts. Science of the Total Environnement, 104: 191-209.

Barreto R.R., de Farias W.K.T, Andrade H., Santana F.M., Lessa R., 2016. Age, Growth and Spatial Distribution of the Life Stages of the Shortfin Mako, Isurus oxyrinchus (Rafinesque, 1810) Caught in the Western and Central Atlantic. PLoS One. 2016; 11(4): e0153062.

Biton Porsmoguer, S. 2015. Biologie, écologie et conservation du requin peau bleue (Prionace glauca) et du requin mako (Isurus oxyrinchus) en Atlantique nord-est. Thèse doctorale. Aix-Marseille Université. 269p

Biton Porsmoguer, S., Bănaru, D., Béarez, P., Dekeyser, I., Merchán Fornelino, M., Míguez Lozano, R., Boudouresque, C.F. 2013. Diet of the shortfin Mako Isurus oxyrinchus and the blue shark Prionace glauca in the northeastern Atlantic Ocean. Rapport Commission Internationale pour 1'Exploration scientifique de la Mer Méditerranée, 40: 499

Biton Porsmoguer, S., Bănaru, D., Boudouresque, C. F., Dekeyser, I, Merchán, M. 2015. DNA evidence of the consumption of short-beaked common dolphin Delphinus delphis by the 
shortfin mako Isurus oxyrinchus, in the Northeastern Atlantic Ocean, Marine Ecology Progress Series, 532: 177-183

Boening D.X., 2000. Ecological effects, transport, and fate of mercury: a general review.

Chemosphere, 40: 1335-1351.

Booth S., Zeller D., 2005. Mercury, food webs, and marine mammals: implications of diet and climate change for human health. Environmental Health Perspectives, 113: 521-526.

Branco, V., Canário, J., Vale, C., Raimundo, J., Reis, C. 2004. Total and organic mercury concentrations in muscle tissue of the blue shark (Prionace glauca L.1758) from the Northeast Atlantic. Baseline / Marine Pollution Bulletin, 49: 854-874.

Branco V., Vale C., Canário J., Santos M.N., 2007. Mercury and selenium in blue shark (Prionace glauca, L. 1758) and swordfish (Xiphias gladius, L. 1758) from two areas of the Atlantic Ocean. Environ. Pollut., 150: 373-380.

Cabana G., Rasmussen J.B., 1994. Modelling food chain structure and contaminant bioaccumulation using stable nitrogen isotopes. Nature, 372: 255-257.

Carey, F. G. 1982. Warm fish. In: C. R. Taylor, K. Johansen \& L. Bolis, eds., A companion to animal physiology. Cambridge University Press, Chapt. 16: 216-233.

Castalodi A.F., Coccini T., Manzon L., 2003. Neurotoxic and molecular effects of methylmercury in humans. Rev. Environ Health, 18: 19-31.

Compagno, L., Dando, M., Fowler, S. 2005. Guía de campos de los tiburones del mundo. Barcelona, Ediciones Omega, 357p.

Cossa D., Averty B., Pirrone N., 2009. The origin of methylmercury in open Mediterranean waters. Limnol. Oceanogr., 54 : 837-844.

Cossa, D., Harmelin-Vivien, M., Mellon-Duval, L., Loizeau, V., Averty, B., Crochet, S., Chou, L., Cadiou, J.-F. 2012. Influence of bioavaibility, trophic position and growth on methylmercury in hakes (Merluccius merluccius) from northwestern Mediterranean and northeast Atlantic. Environmental Sciences and Technology, 46: 4885-4893

Council Regulation (EC) No. 1185/2003 of 26 June of 2003 on the removal of fins of sharks on board vessels. Official Journal of the European Union L 167/1, 26 June 2003, 3p

Cresson, P., Fabri, M. C., Bouchoucha, M., Brach Papa, C., Chavanon, F., Jadaud, A., Knoery, J., Miralles, F., Cossa, D. 2014. Mercury in organisms from the Northwestern 
Mediterranean slope: Importance of food sources. Science of the Total Environnement 497-498: 229-238

Davenport, S. 1995. Mercury in blue sharks and deepwater dogfish from around Tasmania. Australian Fisheries, 54 (3): 20-22.

de Carvalho G.G.A., Degaspari I.A.M., Branco V., Canário J., Ferreira de Amorim A., Kennedy V.H., Ferreira J.R. (2014) Assessment of total and organic mercury levels in blue sharks (Prionace glauca) from the South and Southeastern Brazilian Coast. Trace Elem. Res., 159: 128-134.

Dias, A. C. L., Guimarães, J. R. D., Malm. O., Costa, P. A. S. 2008. Total mercury in muscle of the shark Prionace glauca (Linnaeus, 1758) and swordfish Xiphias gladius Linnaeus, 1758, from the South-Southeast coast of Brazil and the implications for public health. Cad. Saúde Pública, Rio de Janeiro, 24(9): 2063-2070

Díez, S. 2008. Human health effects of methylmercury exposure. In: D.M. Whitacre (ed.) Reviews of Environmental Contamination and Toxicology, 198: 111-132.

Domi N., Bouquegneau J.M., Das K., 2005. Feeding ecology of five commercial shark species from the Celtic Sea through stable isotope and trace metal analysis. Marine Environmental Research,

Escobar-Sánchez O., Galván-Magaña F., Rosíles-Martínez R., 2011. Biomagnification of mercury and selenium in blue shark Prionace glauca from the Pacific Ocean off Mexico. Biol Trace Elem Res 144:550-559.

European Commission, 2006. Commission Regulation (EC) No 1881/2006 of 19 December 2006 setting maximum levels for certain contaminants in foodstuffs. Off. J. Eur. Communities: Legis 37:4. ELI: http://data.europa.eu/eli/reg/2006/1881/2015-05-21

Ferretti, F., Worm, B., Britten, G.L., Heithaus, M.R., Lotze, H.K. 2010. Patterns and ecosystem consequences of shark declines in the ocean. Ecology Letter, 13: 1055-1071

Fisk, A.T., Hobson, K.A., Norstrom, R.J., 2001. Influence of chemical and biological factors on trophic transfer of persistent organic pollutants in the Northwater Polynia marine food web. Environmental Science and Technology 35, 732-738.

Gray J.S., 2002. Biomagnification in marine systems: the perspective of an ecologist. Marine Pollution Bulletin, 45: 46-52. 
Guest, J. E., Gaspar, J. L., Cole, P. D., Queiroz, G., Duncan, A. M., Wallestein, N., Ferreira, T., Pacheco, J-M., 1999. Volcanic geology of Furnas Volcano, Sao Miguel, Azores. Journal of Volcanology and Geothermal Research, 92: 1-29

Harmelin-Vivien M., Bodiguel X., Charmasson S., Loizeau V., Mellon-Duval C., Tronczyński J., Cossa D. 2012. Differential biomagnification of PCB, PBDE, Hg and Radiocesium in the food web of the European hake from the NW Mediterranean. Marine Pollution Bulletin, 64: 974-983.

Harmelin-Vivien, M., Cossa, D., Crochet, S., Bănaru, D., Letourneur, Y., Mellon-Duval, C. 2009. Difference of mercury bioaccumulation in red mullets from the north-western Mediterranean and Black seas. Marine Pollution Bulletin, 58: 679-685

Hussey NE, MacNeil MA, Olin JA et al (2012) Stable isotopes and elasmobranchs: tissue types, methods, applications and assumptions. J Fish Biol 80:1449-1484

ICCAT. 2015. Report of the 2015 ICCAT Blue Shark stock assessment session. Portugal 2015: $1-115$

Instituto Español de Oceanografía (IEO). 2003. Niveles de arsénico y metales pesados en Marrajos (Isurus oxyrinchus), Pez espada (Xiphias gladius) y Tintorera (Prionace glauca). Informe final. Convenio específico de colaboración entre la Secretaría General de Pesca Marítima y el Instituto Español de Oceanografía. 48p

Kaneko J.J., Ralston N.V., 2007. Selenium and mercury in pelagic fish in the central North Pacific near Hawaii. Biol. Trace Elem. Res., 119: 242-254.

Khan M.A.K., Wang F., 2009. Mercury-selenium compounds and their toxicological significance: Toward a molecular understanding of the mercury-selenium antagonism. Environ. Toxicol. Chem., 28: 1567-1577.

Kohler N.E., Turner P.A., Hoey J.J., Natanson L.J., Briggs R., 2002. Tag and recapture data for three pelagic shark species: blue shark (Prionace glauca), shortfin mako (Isurus oxyrinchus) and porbeagle (Lamna nasus) in the north Atlantic Ocean. Collective Volume of Scientific Papers. ICCAT, 54 (4): 1231-1260.

Lavoie R.A., Jardine T.D., Chumchal MM, Kidd K.A, Campbell L.M., 2013. Biomagnification of mercury in aquatic food webs: A worldwide meta-analysis. Environ Sci Technol 47: $13385-13394$. 
Magalhães, M.C., Costa, V., Menezes, G.M., Pinho, M.R., Santos, R.S., Monteiro, L.R. 2007. Intra- and interspecific variability in total and methylmercury bioaccumulation by eight marine fish species from the Azores. Marine Pollution Bulletin, 54: 1654-1662.

Maz-Courrau, A., López-Vera, C., Galván-Magaña, F., Escobar-Sánchez, O., Rosíles-Martínez, R., Sanjuán-Muñoz, A. 2012. Bioaccumulation and Biomagnification of Total Mercury in Four Exploited Shark Species in the Baja California Peninsula, Mexico. Bulletin of Environmental Contamination and Toxicology, 88: 129-134

McKinley, A. and Johnston, E. L. 2010. Impacts of contaminant sources on marine fish abundance and species richness: a review and meta-analysis of evidence from the field. Marine Ecology Progress Series, 420, 175-191.

McKinney M.A., Dean K., Hussey N.E., Cliff G., Wintner S.P., Dudley S.F.J., Zungu M.P., Fisk A.T., 2016. Global versus local causes and health implications of high mercury concentrations in sharks from the east coast of South Africa. Science of theTotal Environment, 541: 176-183.

McMeans B.C., Svavarsson J., Dennard S., Fisk A.., 2010. Diet and resource use among Greenland sharks (Somniosus microcephalus) and teleosts sampled in Icelandic waters, using d13C, d15N, and mercury. Can J Fish Aquat Sci., 67:1428-1438.

Moreno, J.A. 2004. Guía de los tiburones de aguas ibéricas, Atlántico nororiental y Mediterráneo. Barcelona, Omega publ. 315p.

Nakano, H. and Stevens, J. D. 2008. The biology and ecology of the blue shark, Prionace glauca; pp. 140-151. In Sharks of the Open Ocean: Biology, Fisheries and Conservation. Edited by M. D. Camhi, E. K. Pikitch, and E. A. Babcock. Blackwell Publishing. Oxford, U.K.

Natanson L.J., Kohler N.E., Ardizzone D., Cailliet G.M., Wintner S.P., Mollet H.F., 2006. Validated age and growth estimates for the shortfin mako, Isurus oxyrinchus, in the North Atlantic Ocean. Environ. Biol. Fish., 77: 367-383.

Pethybridge H., Cossa D., Butler E.C.V. 2010. Mercury in 16 demersal sharks from southeast Australia: Biotic and abiotic sources of variation and consumer health implications. Marine Environmental Research, 69: 18-26.

Queiroz, N., Humphries, N.E., Mucientes, G., Hammerschlag, N., Lima, F.P., Scales, K.L., Miller, P.I., Sousa, L.L., Seabra, R., Sim, D.W. Ocean-wide tracking of pelagic sharks 
reveals extent of overlap with longline fishing hotspots. Proceedings of the National Academy of Sciences. DOI: 10.1073/pnas.1510090113

Rumbold D., Wasno R., Hammerschlag N., Volety A., 2014. Mercury accumulation in sharks from the coastal waters of southwest Florida. Arch. Environ. Contam. Toxicol., 67: 402412.

Shadwick R.E., Goldbogen J.A., 2003. Muscle function and swimming in sharks. J. Fish. Biol., 80: 1904-1939.

Skomal G.B., Natanson L.J., 2003. Age and growth of the blue shark (Prionace glauca) in the North Atlantic Ocean. Fish. Bull., 101: 627-639.

Storelli, M. M., Giacominelli-Stuffler, R., Marcotrigiano, G. O. 2001. Total mercury and methymercury in tuna fish and sharks from the south Adriatic Sea. Italian Journal of Food Science, 13: 101-106

Storelli, M. M., Giacominelli-Stuffler, R., Marcotrigiano, G. O. 2002. Mercury accumulation and speciation in muscle tissue of different species of sharks from Mediterranean Sea, Italy. The Bulletin of Environmental Contamination and Toxicology, 68: 201-210

Suk, S. S., Smith, S. E., Ramon, D. A. 2009. Bioaccumulation of mercury in pelagic sharks from the Northeast Pacific Ocean. California Cooperative Oceanic Fisheries Investigations Reports, 50: 172-177

Teffer, A. K. 2012. Heavy Metal Food Chain: Relating Feeding Ecology and Mercury Bioaccumulation in Southern New England's Top Pelagic Predators. Master's Thesis. University of Massachussets, Amherst, MA

Trudel M., Rasmussen J.B., 2006. Bioenergetics and mercury dynamics in fish: a modelling perspective. Can J Fish Aquat Sci 63:1890-1902.

Vandeperre, F., Aires-da-Silvas, A., Fontes, J., Santos, M. Serrao Santos, R., Afonso, P. 2014. Movements of Blue Sharks (Prionace glauca) across Their Life History. PLoS ONE 9(8): e103538. doi:10.1371/journal.pone.0103538

Xunta de Galicia. 2008. Ley 11/2008, del 3 de Diciembre, de pesca de Galicia. Publicado en DOG núm. 243 de 16 de Diciembre de 2008 y BOE núm. 15 de 17 de Enero de 2009 


\section{Tables}

Table 1. Number of individuals analyzed by sex, season, year and zone. M: Male, F: Female.

\begin{tabular}{|c|c|c|c|c|c|c|c|c|c|c|c|c|}
\hline \multirow{2}{*}{ Species } & \multicolumn{2}{|c|}{ Sex } & \multicolumn{2}{|c|}{ Season } & \multicolumn{2}{|c|}{ Year } & \multicolumn{6}{|c|}{ Zone } \\
\hline & $\mathbf{M}$ & $\mathbf{F}$ & Winter & Summer & 2012 & 2013 & $\mathbf{A}$ & B & $\mathbf{C}$ & D & $\mathbf{E}$ & $\mathbf{F}$ \\
\hline Blue shark & 20 & 20 & 18 & 22 & 19 & 21 & 18 & 11 & 0 & 9 & 0 & 2 \\
\hline Shortfin mako & 26 & 22 & 18 & 30 & 18 & 30 & 9 & 16 & 13 & 0 & 7 & 3 \\
\hline
\end{tabular}

Table 2. Mean $\pm \mathrm{SD}(\min -\max )$ total length $(\mathrm{TL} \mathrm{cm})$, total weight (ww $\mathrm{kg}$ ), total $\mathrm{Hg}$ concentration ( $\left.\mathrm{mg} \mathrm{kg}^{-1} \mathrm{ww}\right)$ and $\delta^{15} \mathrm{~N}(\%)$ of the blue shark and shortfin mako analyzed.

\begin{tabular}{lllll}
\hline Species & $\mathrm{TL}(\mathrm{cm})$ & $\mathrm{W}(\mathrm{kg})$ & $\mathrm{Hg}\left(\mathrm{mg} \mathrm{kg}^{-1} \mathrm{ww}\right)$ & $\delta^{15} \mathrm{~N}(\%)$ \\
\hline Blue shark & $160 \pm 56$ & $21.0 \pm 21.2$ & $0.52 \pm 0.35$ & $11.3 \pm 0.8$ \\
& $(74-284)$ & $(1.5-77.0)$ & $(0.14-1.71)$ & $(10.0-13.7)$ \\
\hline Shortfin mako & $156 \pm 36$ & $40.3 \pm 62.7$ & $0.74 \pm 0.56$ & $11.8 \pm 0.6$ \\
& $(100-219)$ & $(7.0-76.8)$ & $(0.12-2.57)$ & $(9.6-12.9)$ \\
\hline
\end{tabular}


Table 3. Mean $( \pm \mathrm{SD}) \mathrm{Hg}$ concentration $\left(\mathrm{mg} \mathrm{kg}^{-1} \mathrm{ww}\right)$ and trophic level $\left(\delta^{15} \mathrm{~N}\right)$ in the various prey of blue shark and shortfin mako. $\mathrm{N}=$ number of samples analyzed; unid. = unidentified

\begin{tabular}{|c|c|c|c|c|}
\hline Prey type & $\mathrm{N}$ & $\mathrm{Hg}\left(\mathrm{mg} \mathrm{kg}^{-1} \mathrm{ww}\right)$ & $\mathrm{N}$ & $\delta^{15} \mathrm{~N}(\% 0)$ \\
\hline \multicolumn{5}{|l|}{ Cephalopods } \\
\hline Ancistroteuthis lichteinii & 1 & 1.17 & 3 & $12.9(0.1)$ \\
\hline Gonatus steenstrupi & 1 & 0.23 & 3 & $10.7(0.1)$ \\
\hline Illex coindetii & 1 & 0.20 & 3 & $11.3(0.1)$ \\
\hline Illex sp. & 1 & 2.24 & 3 & $11.7(0.1)$ \\
\hline Cephalopods unid. & 6 & $1.24(0.86)$ & 12 & $12.1(0.9)$ \\
\hline \multicolumn{5}{|l|}{ Teleost fish } \\
\hline Balistes capriscus & 1 & 0.06 & 3 & $10.1(0.1)$ \\
\hline Euthynnus alleteratus & 2 & $1.08(1.07)$ & 6 & $9.7(0.3)$ \\
\hline Scomberesox saurus & 8 & $0.08(0.03)$ & 12 & $11.2(0.5)$ \\
\hline Scomber scombrus & 3 & $0.13(0.08)$ & 9 & $11.2(0.2)$ \\
\hline Scomber sp. & 2 & $0.02(0.001)$ & 6 & $12.2(0.6)$ \\
\hline Thunnus alalunga & 3 & $1.35(0.09)$ & 9 & $11.8(0.5)$ \\
\hline Xiphias gladius & 1 & 1.43 & 3 & $12.0(0.2)$ \\
\hline Teleosts unid. & 3 & $0.20(0.21)$ & 9 & $11.1(0.1)$ \\
\hline \multicolumn{5}{|l|}{ Chelonians } \\
\hline Caretta caretta & 1 & 0.59 & 3 & $9.8(0.1)$ \\
\hline \multicolumn{5}{|l|}{ Cetaceans } \\
\hline Delphinus delphis & 2 & $1.77(0.36)$ & 6 & $10.6(0.5)$ \\
\hline Cetaceans unid. & 2 & $0.46(0.05)$ & 6 & $10.9(0.1)$ \\
\hline
\end{tabular}


Table 4. $\mathrm{Hg}$ concentration $\left(\mathrm{mg} \mathrm{kg}^{-1} \mathrm{ww}\right)$ and $\delta^{15} \mathrm{~N}(\%)$ in the two shark species and their respective diet, and biomagnification factor (BMF) calculated from sharks to their diet in all individuals combined and in the different size classes analyzed (T1-T5), $\mathrm{N}=$ number of individuals analyzed.

\begin{tabular}{|c|c|c|c|c|c|c|}
\hline Species & $\mathrm{N}$ & $\begin{array}{c}\text { Hg-shark } \\
\left(\mathrm{mg} \mathrm{kg}^{-1} \mathrm{ww}\right)\end{array}$ & $\begin{array}{c}\delta^{15} \mathrm{~N} \text {-shark } \\
(\%)\end{array}$ & $\begin{array}{l}\text { Mean Hg-diet } \\
\left(\mathrm{mg} \mathrm{kg}^{-1} \mathrm{ww}\right)\end{array}$ & $\begin{array}{c}\text { Mean } \delta^{15} \mathrm{~N} \text {-diet } \\
(\% \text { ) }\end{array}$ & BMF \\
\hline Blue shark & 40 & 0.52 & 11.3 & 0.95 & 11.8 & 0.57 \\
\hline $\mathrm{T} 1(<100 \mathrm{~cm} \mathrm{TL})$ & 6 & 0.25 & 11.3 & 1.06 & 11.8 & 0.25 \\
\hline $\mathrm{T} 2(100-129 \mathrm{~cm} \mathrm{TL})$ & 9 & 0.36 & 11.0 & 1.12 & 11.9 & 0.35 \\
\hline T3 $(130-159 \mathrm{~cm} \mathrm{TL})$ & 8 & 0.37 & 11.3 & 1.05 & 11.8 & 0.37 \\
\hline T4 $(160-200 \mathrm{~cm} \mathrm{TL})$ & 7 & 0.62 & 11.6 & 0.68 & 11.5 & 0.91 \\
\hline T5 (>200 cm TL) & 10 & 0.86 & 11.3 & 1.03 & 10.9 & 0.80 \\
\hline Shortfin mako & 48 & 0.74 & 11.8 & 0.61 & 11.6 & 1.19 \\
\hline T2 $(100-129 \mathrm{~cm} \mathrm{TL})$ & 11 & 0.28 & 11.4 & 0.65 & 11.1 & 0.42 \\
\hline T3 $(130-159 \mathrm{~cm} \mathrm{TL})$ & 16 & 0.75 & 11.5 & 0.69 & 11.5 & 1.09 \\
\hline T4 $(160-200 \mathrm{~cm} \mathrm{TL})$ & 12 & 0.54 & 12.1 & 0.84 & 11.3 & 0.60 \\
\hline T5 (>200 cm TL) & 9 & 1.59 & 12.0 & 0.59 & 10.1 & 2.26 \\
\hline
\end{tabular}


Table 5. Mercury levels in the blue shark (Prionace glauca) and the shortfin mako (Isurus oxyrinchus) in the Atlantic and other oceans. ${ }^{*}=$ mean values; $\mathrm{TL}=$ total length of individuals $(\mathrm{cm}) ; \mathrm{Hg}=$ total $\mathrm{Hg}$ concentration in muscle $\left(\mathrm{mg} \mathrm{kg}^{-1} \mathrm{ww}\right)$; Ref. = reference of the study cited.

\begin{tabular}{|c|c|c|c|c|c|c|}
\hline \multirow[b]{2}{*}{ Region } & \multicolumn{3}{|c|}{ Blue shark } & \multicolumn{3}{|c|}{ Shortfin mako } \\
\hline & $\begin{array}{l}\mathrm{TL} \\
(\mathrm{cm})\end{array}$ & $\begin{array}{c}\text { Hg } \\
\left(\mathrm{mg} \mathrm{kg}^{-1} \text { ww) }\right.\end{array}$ & Ref. & $\begin{array}{c}\mathrm{TL} \\
(\mathrm{cm})\end{array}$ & $\begin{array}{c}\mathrm{Hg} \\
\left(\mathrm{mg} \mathrm{kg}^{-1} \mathrm{ww}\right)\end{array}$ & $\begin{array}{c}\text { Ref } \\
\text {. }\end{array}$ \\
\hline Azores \& Iberian Peninsula (NE Atlantic) & $79-284$ & $0.14-1.71$ & (1) & $100-219$ & $0.12-2.57$ & (1) \\
\hline Azores Archipelago (NE Atlantic) & $97-210$ & $0.16-1.84$ & (2) & - & - & \\
\hline Canary Islands (NE Atlantic) & $216-258$ & $0.16-1.84$ & (2) & - & - & \\
\hline New England (North Atlantic) & - & - & & - & 2.65 & (8) \\
\hline North Atlantic & $160-274$ & $1.25^{*}$ & (3) & $106-285$ & $3.12 *$ & (3) \\
\hline South Atlantic & $122-274$ & $1.01 *$ & (3) & $94-262$ & $2.14^{*}$ & (3) \\
\hline Brazil (South Atlantic) & $77-137$ & $0.46-2.40$ & $(4,5)$ & - & - & \\
\hline Indian Ocean & $164-269$ & $1.24 *$ & (3) & $119-262$ & $2.34 *$ & (3) \\
\hline South Africa (Indian Ocean) & - & - & & $161-220$ & $2.69^{*}$ & (9) \\
\hline Tasmania (Pacific Ocean) & $89-335$ & $0.27-1.20$ & (6) & - & - & \\
\hline Baja California (Pacific Ocean) & - & - & & $127 \pm 40$ & $1.05^{*}$ & $(10)$ \\
\hline California (Pacific Ocean) & - & - & & $75-330$ & $0.15-2.90$ & $(11)$ \\
\hline Hawaï (Pacific Ocean) & - & - & & $105-240$ & $0.40-3.10$ & $(11)$ \\
\hline Adriatic Sea (Mediterranean) & - & $0.38^{*}$ & (7) & - & - & \\
\hline
\end{tabular}

(1) Present study, (2) Branco et al. (2004), (3) IEO (2003), (4) Dias et al. (2008), (5) Carvalho et al. (2014), (6) Davenport (1995), (7) Storelli et al. (2001), (8) Teffer (2012), (9) McKinney et al. (2016), (10) Maz-Courrau et al. (2012), (11) Suk et al. (2009) 
Fig. 1.
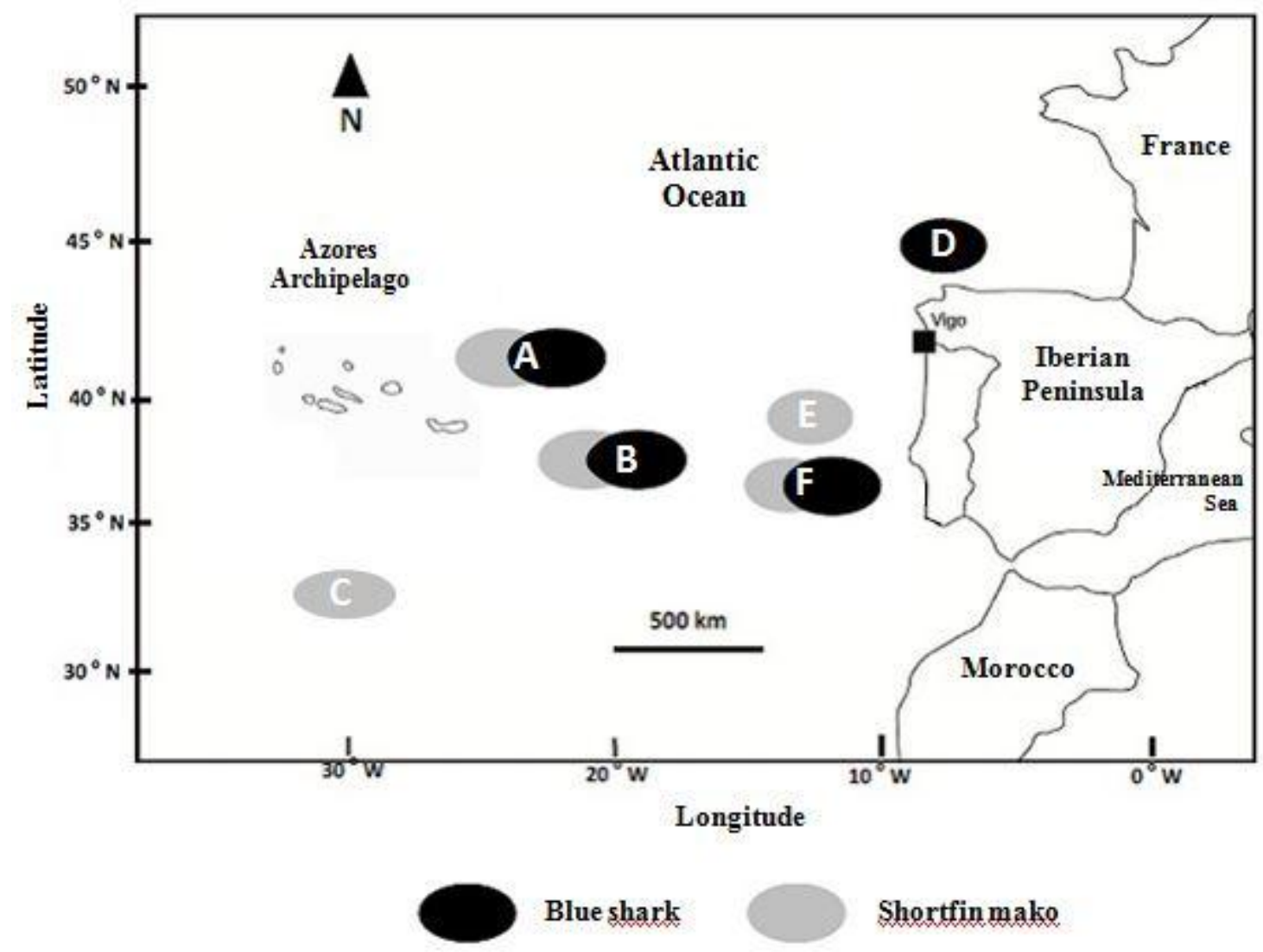

Fig. 1. Map of sampling areas between the Azores Archipelago and the Iberian Peninsula (Northeastern Atlantic Ocean). 
Fig. 2.

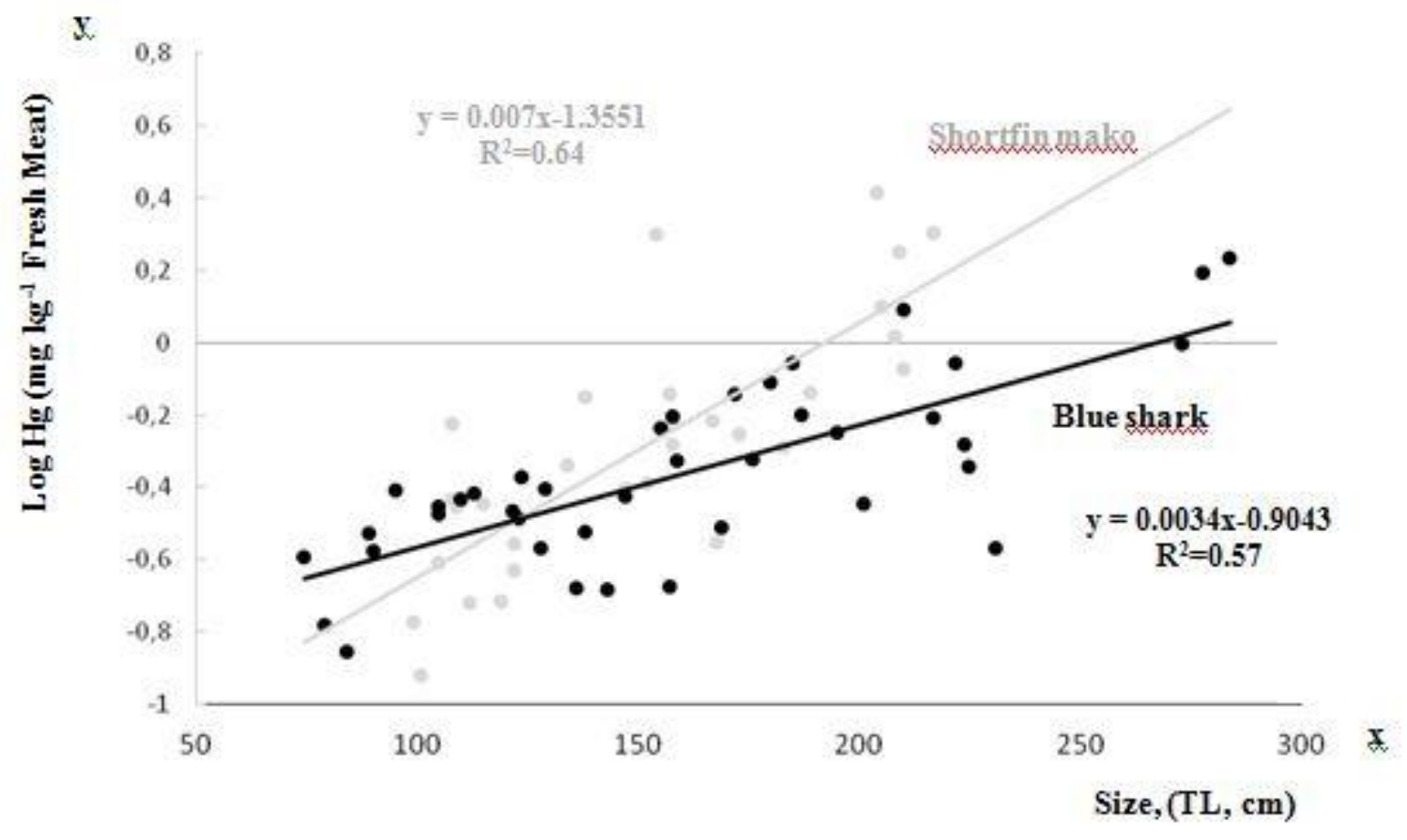

. Fig. 2. Correlation between $\log _{10} \mathrm{Hg}$ and size in blue shark $(\mathrm{N}=40)$ and shortfin mako $(\mathrm{N}=48)$ 
Fig. 3.

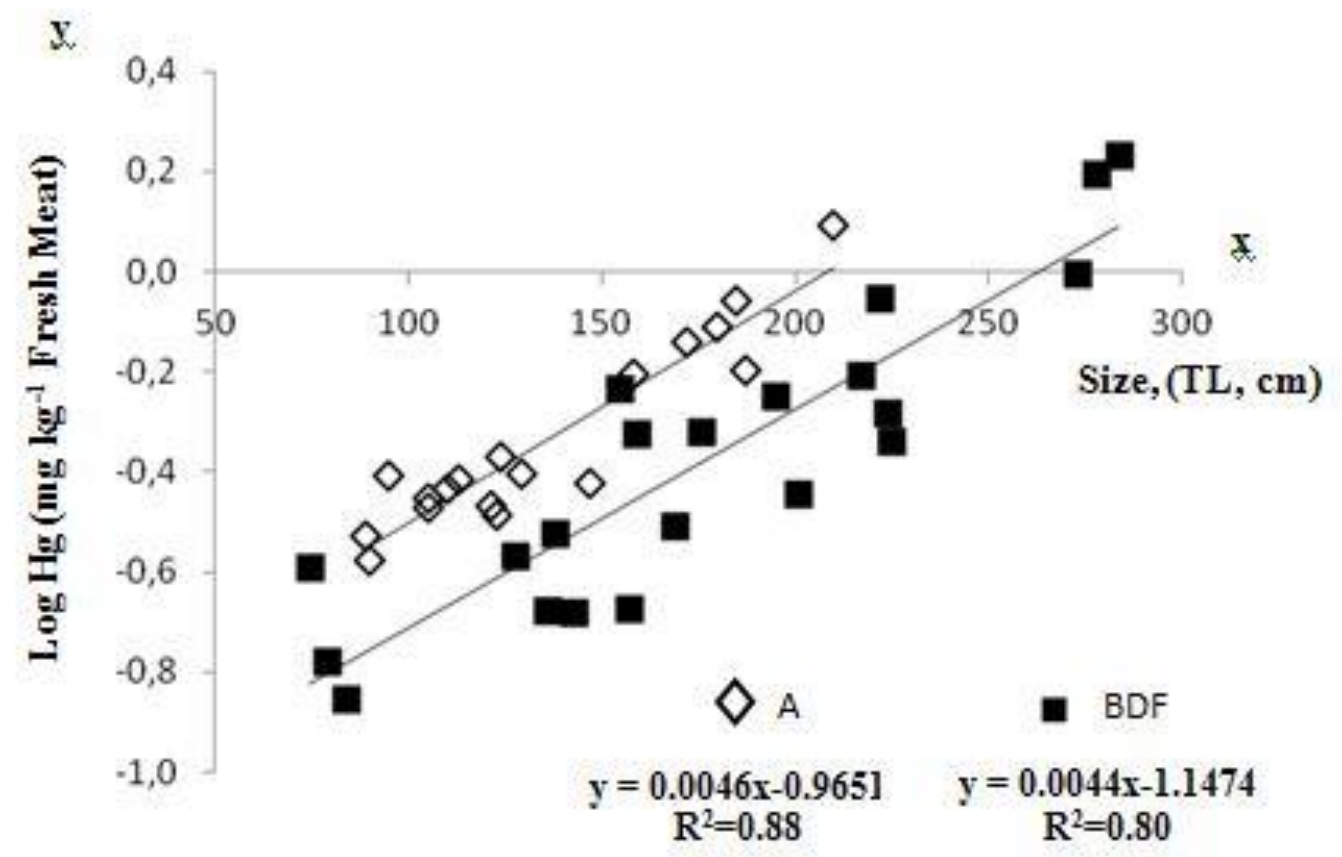

Fig.3. Spatial difference of correlation between $\mathrm{Log} \mathrm{Hg}$ and size in the blue shark in zone A (northeast of the Azores) compared with the other sampling zones (B, D and F). 
Fig. 4.

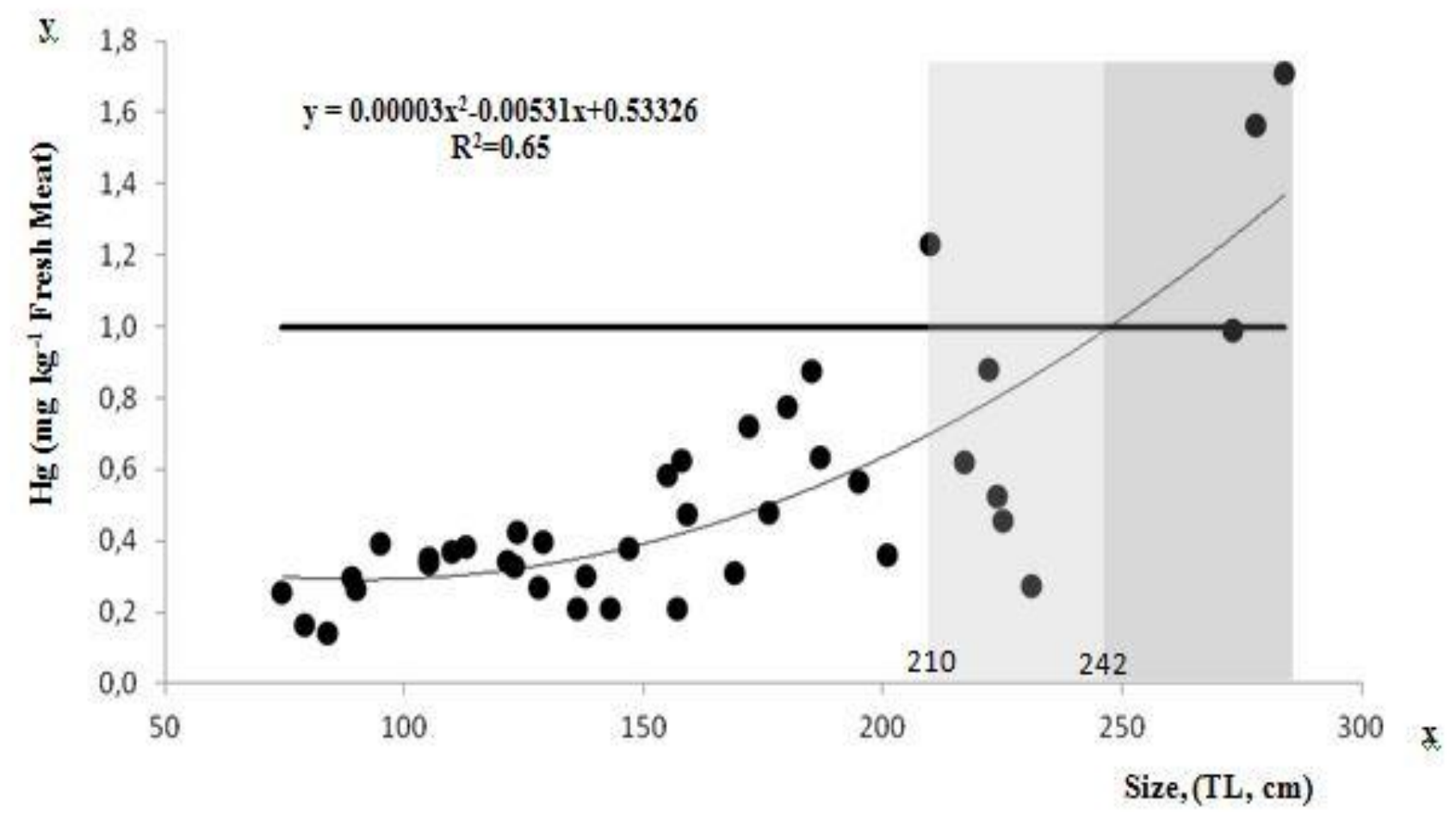

Fig. 4. Correlation between $\mathrm{Hg}$ level $\left(\mathrm{mg} \mathrm{kg}^{-1} \mathrm{ww}\right)$ and total length $(\mathrm{cm})$ in the blue shark. The horizontal bold line corresponds to the European regulatory threshold $\left(1.0 \mathrm{mg} \mathrm{kg}^{-1} \mathrm{ww}\right)$ for commercialization. The light grey area indicates the size range of potential risk (some fish above the threshold) and the dark grey area starts at the size at risk (from which most fish exceed the threshold). The numbers above the $\mathrm{x}$ axis indicate the lower size limit in $\mathrm{cm}$ of these two areas. 
Fig. 5.

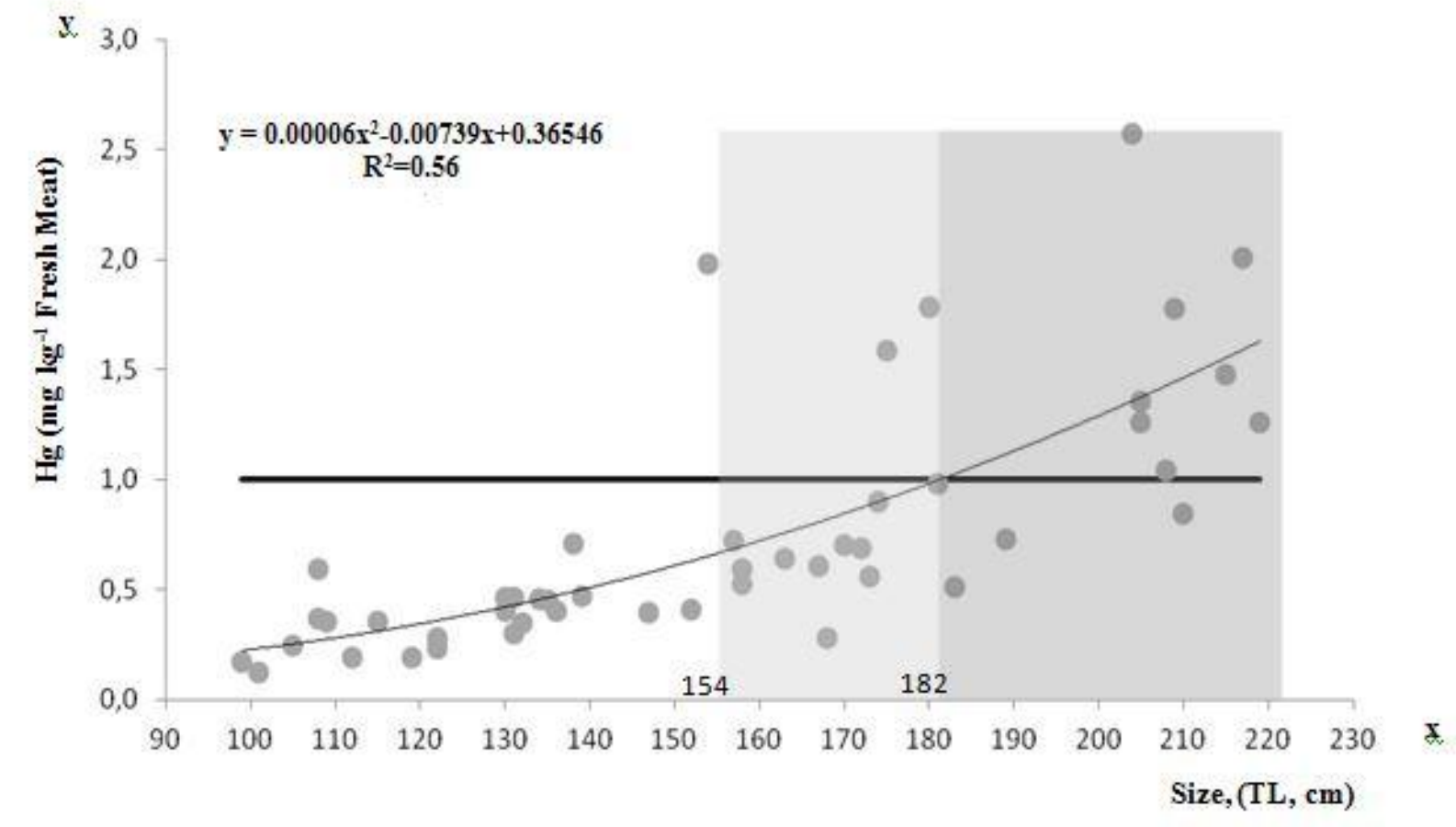

Fig. 5. Correlation between $\mathrm{Hg}$ level $\left(\mathrm{mg} \mathrm{kg}^{-1} \mathrm{ww}\right)$ and total length $(\mathrm{cm})$ in the shortfin mako. The horizontal bold line corresponds to the European regulatory threshold $\left(1.0 \mathrm{mg} \mathrm{kg}^{-1} \mathrm{ww}\right)$ for commercialization. The light grey area indicates the size range of potential risk (some fish above the threshold) and the dark grey area starts at the size at risk (from which most fish exceed the threshold). The numbers above the $\mathrm{x}$ axis indicate the lower size limit in $\mathrm{cm}$ of these two areas. 